TOTOBUANG

$\begin{array}{lll}\text { Volume } 5 & \text { Nomor 2, Desember } 2017 & \text { Halaman 187-198 }\end{array}$

\title{
GONE GIRL DARI DAVID FINCHER: DESKRIPTIF GEJALA PSIKOPAT DITUNJUKKAN OLEH KARAKTER AMY ELLIOT DUNNE \\ (David Fincher's Gone Girl: Description of Psychopathic Symptoms Reflected on Amy Elliot Dunne's Character)
}

\author{
Rodelio Paparang Lalenoh \& Novita Julhijah \\ STBA Pontianak \\ Jl. Gajah Mada No. 38-44, Pontianak \\ Pos-el: nellio21@yahoo.co.id
}

(Diterima: 31 Oktober 2017; Direvisi 13 November 2017; Disetujui: 29 Desember 2017)

\begin{abstract}
This research was intended to reveal the psychopathic symptoms that shown by Amy Elliot Dunne's in Gone Girl film by applying Dr. Hare's Psychopathy Checklist-Revised 2nd Version (PCL-R) as the main theory of the whole description in the film. The writer used descriptive-qualitative method to simply collect all the data from accessible books, journal, and official website. Furthermore, these were used to analyze the psychopathic symptoms through the character's behavior, dialogue, monologue, and narration. The writer revealed Nick's disloyal lifestyle to his marriage and followed by Nick's cheating on Amy drive Amy to be a psychopath. Conclusively, the writer reveals psychopathic symptoms depicted on Amy: Glib and Superficial Charm, Pathological Lying, Conning and Manipulative, Lack of Remorse and Guilt, Callous and Lack of Empathy, Shallow Affect, Parasitic Lifestyle, Poor Behavioral Control, Promiscuous Sexual Behavior, and Criminal Versatility.

Keywords: literature and psychology, film, characterization, psychopathic symptoms

Abstrak

Penelitian berikut bermaksud untuk mengungkap gejala-gejala psikopat yang di tunjukan oleh Amy Elliot Dunne di film Gone Girl dengan mengaplikasikan Psychopathy Checklist Revised Versi ke-2 (PCL-R) milik Dr. Hare sebagai teori utama di semua deskripsi pada film tersebut. Penulis menggunakan pendekatan deskriptifkualitatif untuk mengumpulkan semua data dari buku yang dapat diakses, jurnal, dan website resmi. Selebihnya, ini akan digunakan untuk menganalisa gejala-gejala psikopat melalui sifat karakter, dialog, monolog, dan narasi. Penulis mengungkapkan cara hidup Nick yang tidak setia terhadap pernikahan dan diikuti oleh Nick yang selingkuh terhadap Amy memicu Amy menjadi psikopat, Kesimpulannya, penulis mengungkapkan gejala yang di tunjukan Amy: Glib and Superficial Charm, Pathological Lying, Conning and Manipulative, Lack of Remorse and Guilt, Callous and Lack of Empathy, Shallow Affect, Parasitic Lifestyle, Poor Behavioral Control, Promiscuous Sexual Behavior, dan Criminal Versatility.

Kata-kata kunci: sastra dan psikologi, film, karakterisasi, gejala psikopat
\end{abstract}

\section{INTRODUCTION}

Literature is not outside part of psychology but rather has a mutual relation to one another (Dastmard et al., 2012: 9423). The human's psychological unconscious side can be included in literature, and it is an interesting approach to its interpretation towards literature and literary critics; as mostly known as literary psychoanalysis. In psychological review techniques in stories make this interesting, thus its influence towards public's perception of mental illness is important since many people are poorly informed about mental illness (Leistedt et al., 2013: 1). Furthermore, Psychology works the same page in the literature, and function of psychology and its elements is related to literature. Additionally, Film is one of many ways to express feeling and emotion through characters' efforts, experiences, thoughts and 
ideas as well as one of the main entertainment at the present time, similarly film gives many impacts to everyone who is willing to spend time watching it as a refreshing time because of its audio-visual capability makes the whole process of film becomes interesting to watch (Hasson et al., 2008: 1). Therefore, in watching film there are lot of genres can be selected as the criteria of the film that mostly people intend to watch such as: action, comedy, drama, fiction, horror, psychological, thriller, and else. Each genres offer different sensation and intensity in watching film whether it provides sadness, anger, happiness, or terrified. Therefore, film also can be included as one of the sub-parts in literature, as Erica Sheen stated that film and literature offer expressions by applying narratives codes through cinematic, literary, and theoretical illustration. Additionally, The fame of psychopathic character in a film is still indeed fascinated to adore in a decent way, namely Joker in Batman's Dark Night, Hannibal Lecter in The Silence of the Lambs, Norman Bates in Psycho, these characters will be remembered at all time in film's industrialization. However, In 2014, Regency Enterprises and TSG Entertainment accompanied with $20^{\text {th }}$ Century Fox produced one of the finest psychological films introducing one character that is well considered as a psychopathic character by movie-reviewers whom is Amy Eliott Dunne performed by Rosamund Pike. The film entitled Gone Girl is directed by David Fincher based on the novel with the same title written by Gillian Flynn. A film with 149 minutes length tells about the story of Nick Dunne performed by Ben Affleck and Amy Eliott Dunne who are two main characters as a married couple who should have celebrated their fifth anniversary of their marriage in one day, but that day after being reported by his neighbor seeing their pet is outside the house where Nick and Amy are living called "The Missouri Home", Nick immediately goes to home from The Bar which is literally a bar that his sister Margo Dunne are working at thus managing there as well, he shocked after seeing the table of his living room is wrecked upside down, so he presumes that his wife is being taken away and murdered by someone and immediately calls local police to investigate his wife's missing, instead he is being suspected as the one who kills her after the police covering out a blood's stain on the kitchen cabinet and other clues that show all of the evidences which has been found is meant to against him. Surprisingly, all of the crime scenes which are being intended to against Nick are organized by Amy herself on the other word she is faking her dead to convince everyone that her husband is the person who causes her disappearance, this is set up by her to show retaliation to Nick because their marriage is not going like all American-love story, Nick cannot custody their relationship as a married couple, specifically his ongoing affair with other woman who is much younger than him, Nick and Amy often have arguments that ended up with fight. These particular reason make Amy becomes such a psychopathic person. Psychologically Speaking, Gone Girl film can give such a terror-stricken and expose our deepest irrational side unconsciously towards it, as the Pathological Liar and Manipulative Amy Elliot Dunne depicts, assuredly, she is defined as the realistic portrayed of psychopath itself (Niemiec: 2014), by looking at how she is using her charm and feminist's side to frame her death to gain her main goal to have revenge on her husband because of his disloyal marriage life-style, even worse having affair with Andie Fitzgerald (Emily Ratajkowski) who is his creative writing student. Therefore, Based on the characterization which has been described above, the writer intends to reveal the psychopathic symptoms that Amy Elliot Dunne has indicated.

\section{THEORITICAL REVIEW \\ Psychopath}

Moreover, Cope et al (2014: 1) described that psychopath is someone who 
has mental illness characterized by abnormal interpersonal traits, and behaviors. Somehow, psychopathy term cannot be correlated with schizophrenic as World Health Organization (2016) stated that schizophrenic is a symptom with considerable disability that may affect their life performance, conversely with psychopaths who still realize what they will do and have done. The motive psychopaths can be occurred is mostly because they are living in a problematic life condition, such as; inharmonic family, traumatic past in the childhood, being ignored in the past, or genetically and traumatically combined. Psychopathy is the first label as mental disorder (Buzina, 2012: 134). In the early 1800 s, doctors who worked in mental patients labeled psychopath as "moral depravity" and "moral insanity" after noticing some of their patient was behaving abnormally, The term of psychopath first applied in 1900, then changed to sociopath in 1930s, currently researchers have returned to use the term "psychopath" (Hirstein, 2013). Moreover, Psychopath in some cases is acknowledged synonymously with sociopath, which is regularly characterized as a personality problem shown as a person with antisocial behavior, lack of sympathy also guilt, valiant, aggressive, outspoken, show-off, egotistic, forceful, and arrogant characteristics. Kiehl \& Buckholtz (2010: 24) explained the characteristics of psychopaths are not only selfish. Differently with other publics, they commonly interpret and elaborate information with their own understanding through their brains as if they have a difficulty to learn something that occasionally damages their emotional and personality development. Additionally, psychopaths target ruthlessly on others by using their charm, dishonesty, violence or other methods that let them to get with they want. Besides, Psychopaths have their own specific characteristics and traits. Trait describes personal tendencies to do something. Always abandon a relationship or commit crimes are specific sample of traits that will become tendencies and habits. In addition, It is difficult in defining the concept of psychopathy traits since there are so many controversy between experts regarding of diagnosis on this disorder (Buzina, 2012: 134). Moreover, in 2003, a famous Canadian researcher in a field of criminal psychology, Dr. Robert Hare made a list named Psychopathy Checklist-Revised (PCL-R) 2nd Edition, it was firstly used towards prisoners, PCL-R was established as a powerful tool to assess psychopath's serious personality disorder (Bonn, 2015). Dr. Hare (1999: 34) divides it into 20 item symptom rating scales as a tool to determine and measure the characteristic of a person who is considered having psychopathic behavior. Moreover, each symptoms which indicate psychopath's behavior are divided into their particular factors and facets. Factor 1 signifies traits correlated with Interpersonal and Affective deficits of psychopathy, in contrast, factor 2 signifies traits correlated with Antisocial Behavior Lifestyle and high risk of commit suicide, As follows:

Table 1

PCL-R Items Classified Regarding to Factors and Facets

\begin{tabular}{|c|c|}
\hline \multicolumn{2}{|c|}{ PSYCHOPATHY } \\
\hline \multicolumn{2}{|c|}{ FACTOR 1 } \\
\hline Facet 1: Interpersonal & Facet 2: Affective \\
\hline 1. Glibness and Superficial Charm & 6. Lack of Remorse or Guilt \\
2. Grandiose sense of self-worth & 7. Shallow Affect \\
4. Pathological Lying & 8. Callous and Lack of Empathy \\
\hline
\end{tabular}




\begin{tabular}{|c|c|}
\hline 5. Conning and Manipulative & $\begin{array}{l}\text { 16. Failure to Accept Responsibility for own } \\
\text { action }\end{array}$ \\
\hline \multicolumn{2}{|c|}{ FACTOR 2} \\
\hline Facet 3: Lifestyle & Facet 4: Antisocial \\
\hline $\begin{array}{l}\text { 3. Need of Stimulation or Proneness to } \\
\text { Boredom } \\
\text { 9. Parasitic Lifestyle } \\
\text { 13. Lack of Realistic, Long-Term Goals } \\
\text { 14. Impulsivity } \\
\text { 15. Irresponsibility }\end{array}$ & $\begin{array}{l}\text { 10. Poor Behavioral Control } \\
\text { 12. Early Behavioral Problems } \\
\text { 18. Juvenile Delinquency } \\
\text { 19. Revocation of Conditional Release } \\
\text { 20. Criminal Versatility }\end{array}$ \\
\hline \multicolumn{2}{|c|}{$\begin{array}{l}\text { UNIDENTIFIED FACTOR } \\
\end{array}$} \\
\hline $\begin{array}{l}\text { 11. Promiscuous Sexual Behavior } \\
\text { 12. Many Short-Term Marital Relationship } \\
\text { (Dr. Hare, 1999: 34) }\end{array}$ & \\
\hline
\end{tabular}

\section{Psychopathy Checklist-Revised (PCL-R) 2nd Edition:}

1. Glib and Superficial Charm

Hare (2016) stated psychopath always tends to have glibness, fluent, and smooth to persuade others to believe what they say, by using their charm and charisma, they often be smooth, attractive, verbally facile, and not afraid to speak up, their word-playing ability is remarkable. Psychopaths often drive themselves to be public's main attention.

\section{Grandiose Self-Worth}

It is obvious that self-pride and high self-esteem are some of personalities a psychopath has, they often label themselves with some fictional entitlement to show their superiority to other (Verstappen, 2011: 8). They are mostly arrogant people: cocky, arrogant, boast, and braggart are their personalities.

\section{Need for Stimulation or Proneness to Boredom}

Hare stated psychopaths are easily feel bored mainly caused of repetitive, dull or boring activities, therefore, they need an excessive need to comfort themselves and to avoid boredom through exciting stimulation like doing risky things: walking in airport with drugs will excite them.

\section{Pathological Lying}

Psychopaths will tell sort of repeatedly lie as often as they think it should (Sharma et al., 2007: 78). Even when they caught up lying, they would be still calm, take pride even not embarrassed.

\section{Conning and Manipulative}

Distinguished from pathological lying which in order to get attractiveness. Psychopath uses deception to manipulate other people for personal advantage and amusement. They spend their time studying their victim, when to use their victim's emotion for their goal (Verstappen, 2011: 10).

\section{Lack of Remorse or Guilt}

Psychopaths have a lack of concern or feelings for the losses, pain, agony, and suffering of their victims; they may be still calm without any regret even after doing their action. (Verstappen, 2011: 7). 
7. Shallow Affect

American Psychiatric Association (2013: 471) described psychopaths suffer an emotional poverty; do not express feelings or show emotions to other people, be cold-hearted, once they do, that would be seem shallow, two-faced person and can change the emotion displayed; can turn emotions "on" or "off" rapidly. Thus, Psychopaths also get angry if they do not get what they want (Kiehl \& Buckholtz, 2010: 25).

\section{Callousness and Lack of Empathy}

Hare (2016) stated that psychopath unable to get into the skin of others and lack of empathy toward people's feeling; can be cold, inconsiderate, does not cares and insensitive towards each other. Interestingly, they do not totally lack of empathy, they just cannot suddenly empathize, once they do, it is supposed to charm other as a purpose (Keysers, 2013).

\section{Parasitic Lifestyle}

Psychopaths tend to have dependence on others as reflection of lack of motivation, low self-discipline, and incompetence to complete their goals, thus expect other people to support their goals; they will use their charm to seduce their victim's mind to help to achieving their goals.

\section{Poor Behavioral Control}

Psychopaths tend to have reactive characteristic: short-tempered, hotheaded, annoyance, impatience, threats, aggression in order to respond to frustration and failure. Even smallest provocation will trigger their aggressive side. Additionally, this characteristic can be misinterpreted since psychopaths show excellent self-control by pretending to be normal (Verstappen, 2011: 9).

\section{Promiscuous Sexual Behavior}

By using their charm and attractiveness, psychopaths have a lot of different sexual relationships, bunch of affairs, and have sex relationship with any sexual partners, with intention of getting advantages from their prey (Meyers, 2014).

\section{Early Behavior Problems}

Hare stated that most psychopath variety of behaviors started from youth age: including lying, theft, cheating, vandalism, intimidate, alcohol use, cruel to friends, siblings or animal and running away from home. It is happening especially children were raised in violent neighborhood or abusive family.

\section{Lack of Realistic, Long-Term Goals}

Yet again, this can be a misleading since many psychopaths have goals: murdering, sabotage a co-worker, and become a president, however, psychopaths do not have ability to progress and finish long-term plans and goals; aimless, lacking direction in life (Verstappen, 2011: 9).

\section{Impulsivity}

Impulsivity is one of the characteristic of psychopath; do things suddenly based on current mood unconsciously and without considering the effects may have happened afterwards, for them whatever they want is good, whereas things they do not want is considered bad (Verstappen, 2011: 8).

\section{Irresponsibility}

Psychopaths are also being irresponsible (Babiak, 2010: 189). Psychopath repeatedly failure to accomplish responsibilities and 
obligations: not paying their bills, performing messy work, being absent and working late, failing to honor contractual agreements.

\section{Failure to Accept Responsibility for Own Action}

Not only being irresponsible, once psychopaths do a failure, as if it will never be their fault to accept, denial of failure responsibility and blame others over their fault (Verstappen, 2011: 8).

\section{Many Short-Term Marital Relationship}

Psychopaths do not have successful relationships (Meyers, 2014). They have a lack of long-term relationship commitment; tendency to have inconsistent behavior, untrustworthy, and unreliable personality in life, including marriage problem.

\section{Juvenile Delinquency}

Committing crimes between the ages of 13-18 which are considered illegal or not accepted in environment, reflected on psychopath's youth life.

\section{Revocation of Condition Release}

Montana Legislative Services (2015) stated this item is related to psychopath as ex-prisoner who has been on a situation when they repeatedly commit crimes and be revoked; sent to jail and grounded over again. Moreover, it is correlated with psychopath's irresponsibility.

\section{Criminal Versatility}

It is literally means psychopath is able to commit from one crime to another crime for many different advantages purposes and taking great pride of getting away from caught from crimes.

\section{METHODS}

The writer applies descriptivequalitative analysis as a technique of the research. Hancock et al (2009: 7) specified that qualitative research is non-numerical and verbal technique to approach and solve social problem such as: environmental behavior, how social attitudes are formed towards opinion they made or how some events that happened can affect a society, by observing, describing, and defining the data entirely and accurately. In this research, the writer collects data from several accessible books and journals as a resource to support and assist the study through psychological approach. Regarding to the whole steps of conducting this research. Systematically, the writer repeatedly watches the whole film, then cautiously analyzes the traits and behaviors that are exposed on Amy Elliot Dunne's psychopathic character by using Hare's Psychopathy Checklist-Revised: $2^{\text {nd }}$ version $(P C L-R)$ developed by Dr. Robert Hare in 2003. It consists of 20 symptoms as one of the ways to be used in distinguishing and recognizing Amy Elliot Dunne's psychopathic traits. In addition, the writer matches each of the psychopathic symptoms and analyzes the symptoms which only indicate Amy Elliot Dunne's behavior through the movie's scenes, dialogues, monologues and acts the character has shown..

\section{DISCUSSION}

This part discusses about Amy's psychopathic symptom based her characteristic she has shown, by using Hare Psychopathy Checklist Revision $2^{\text {nd }}$ (PCL-R). As follows:

\begin{tabular}{|l|l|l|l|}
\hline No. & \multicolumn{1}{|c|}{$\begin{array}{c}\text { Psychopathic } \\
\text { Symptoms }\end{array}$} & \multicolumn{2}{|c|}{ Result } \\
\cline { 3 - 4 } & \multicolumn{1}{|c|}{ Yes } & No \\
\hline 1. & $\begin{array}{l}\text { Glib and Superficial } \\
\text { Charm }\end{array}$ & $\checkmark$ & \\
\hline 2. & $\begin{array}{l}\text { Grandiose Self- } \\
\text { Worth }\end{array}$ & & $\mathbf{x}$ \\
\hline
\end{tabular}




\begin{tabular}{|c|c|c|c|}
\hline 3. & $\begin{array}{l}\text { Need for Stimulation } \\
\text { or Proneness to } \\
\text { Boredom }\end{array}$ & & $x$ \\
\hline 4. & Pathological Lying & $\checkmark$ & \\
\hline 5. & $\begin{array}{ll}\text { Conning and } & \text { and } \\
\text { Manipulative } & \\
\end{array}$ & $\checkmark$ & \\
\hline 6. & $\begin{array}{l}\text { Lack of Remorse or } \\
\text { guilt }\end{array}$ & $\checkmark$ & \\
\hline 7. & Shallow Affect & $\checkmark$ & \\
\hline 8. & $\begin{array}{l}\text { Callousness and } \\
\text { Lack of empathy }\end{array}$ & $\checkmark$ & \\
\hline 9. & Parasitic Lifestyle & $\checkmark$ & \\
\hline 10. & $\begin{array}{ll}\text { Poor } & \text { Behavioral } \\
\text { Control } & \\
\end{array}$ & $\checkmark$ & \\
\hline 11. & $\begin{array}{l}\text { Promiscuous Sexual } \\
\text { Behavior }\end{array}$ & $\checkmark$ & \\
\hline 12. & $\begin{array}{ll}\text { Early } & \text { Behavior } \\
\text { Problems } & \\
\end{array}$ & & $x$ \\
\hline 13. & $\begin{array}{l}\text { Lack of Realistic, } \\
\text { Long-Term Goals }\end{array}$ & & $x$ \\
\hline 14. & Impulsivity & & $x$ \\
\hline 15. & Irresponsibility & & $x$ \\
\hline 16. & $\begin{array}{l}\text { Failure To Accept } \\
\text { Responsibility For } \\
\text { Own Actions }\end{array}$ & & $x$ \\
\hline 17. & $\begin{array}{l}\text { Many Short-Term } \\
\text { Marital Relationship }\end{array}$ & & $x$ \\
\hline 18. & $\begin{array}{l}\text { Juvenile } \\
\text { Delinquency }\end{array}$ & & $x$ \\
\hline 19. & $\begin{array}{l}\text { Revocation of } \\
\text { Condition Release }\end{array}$ & & $x$ \\
\hline 20. & Criminal Versatility & $\checkmark$ & \\
\hline
\end{tabular}

\section{Glib and Superficial Charm}

Hare (2016) stated psychopath always tends to have glibness, fluent, and smooth to persuade others to believe what they say, by using their charm and charisma, they often be smooth, attractive, verbally facile, and not afraid to speak up, their word-playing ability is remarkable. In Gone Girl Film, Amy is developed as an extremely charming character, by the fact that Nick was the one who approached and flirted with Amy in the party, furthermore about her appearance, Amy is also very adorable and brilliant, she is a real face of fictional Amy in a most popular main character of "Amazing Amy" which is a popular book series written by Amy's parents even Rhonda Boney, the police that investigates Amy's missing case is surprised after finding out that Nick is a husband of Amazing Amy. Everyone in the town loves her so that when she goes missing, every Missourian local citizen are going to location and making banner to help police to search Amy. Amy is a good writer, she is also very good at playing some words like when she leaves the envelope for fifth anniversary to Nick to find out where is the prize is located.

\section{Pathological Lying}

Psychopaths will tell sort of repeatedly lie as often as they think it should be (Sharma et al., 2007: 78). In Gone Girl Film, Amy lies to entire town, the police, media in her motion to fake her dead to make Nick responsible for it, first she lies to Noelle Hawthrone that Nick assaults her to gain her empathy to be a testimony when police is interviewing her.

\section{Amy Narration: "You be friend with local idiot, harvest the detail of her humdrum life And cram her with stories about your husband's violent temper."}

(Scene 129 at minute 01:06:55 - 01:07:07)

When escaping and hiding to small resort after faking her dead scene, Amy also lies to Greta (her neighbor in small resort) that her name is Nancy to fake identity states that she is from New Orleans, but Greta and Jeff rob her after find out Amy has a lot of money in her purse, then Amy asks help from her exboyfriend telling him that Nick abuse her and will kill her and her fake baby.

$$
\begin{aligned}
& \text { Amy: "Last week, I threatened to } \\
& \text { leave, and he said he'd find } \\
& \text { me and he'd kill me, so I }
\end{aligned}
$$


disappeared, I lost the baby, I couldn't even tell my parents, I'm so ashamed and I'm so afraid."

(Scene 214 at minute 01:42:10 - 01:42:30)

After killing Desi and coming home to Nick, Amy also lies to FBI and tells that Desi was kidnapping and brutally abusing her. Ironically, all FBI officers just believe that story. Amy successfully lied to everyone else to complete her masterpiece motion and finally the police closed this case as kidnapping and sets Amy free for killing Desi as self-defense reason.

\section{Conning and Manipulative}

Psychopath uses deception to manipulate other people for personal advantage and amusement (Verstappen, 2011: 10). Furthermore, Amy is known as calculating manipulator, her ability to manipulate people around her is amazing in a bad way, this is shown when Amy finds out that Nick has cheated on her. She begins to fake her dead scene to blame Nick for it by injecting out her blood out and pouring her blood on the floor and cleaning it up, she leaves a small blood stains on the kitchen's cabinet to make an evidence for the police to investigate Nick, thus, hit her eyes to bruise it as indication of physical abused. As proved on images below:

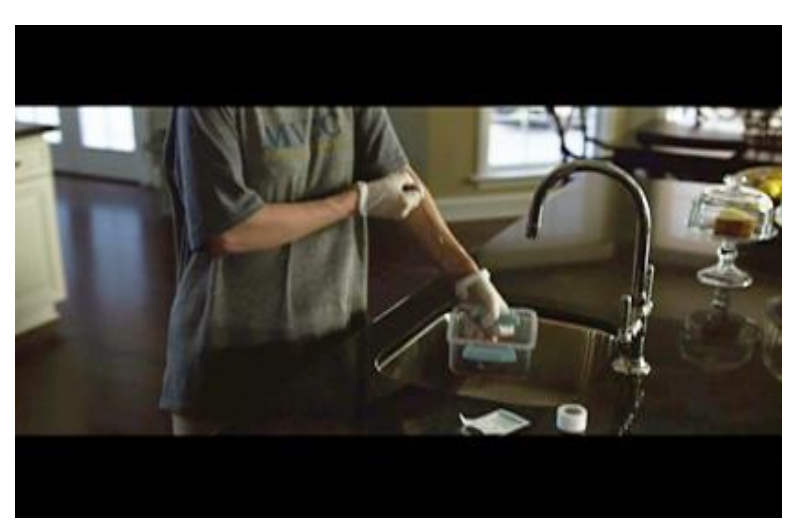

Image 1

Amy fakes death.

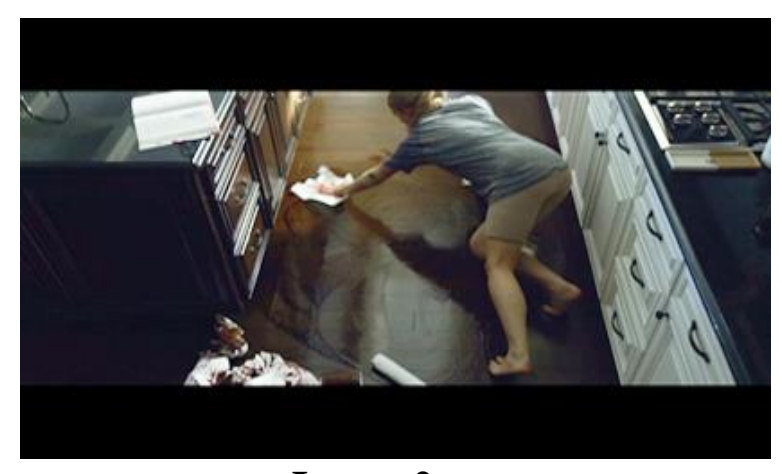

Image 2

Amy fakes death.

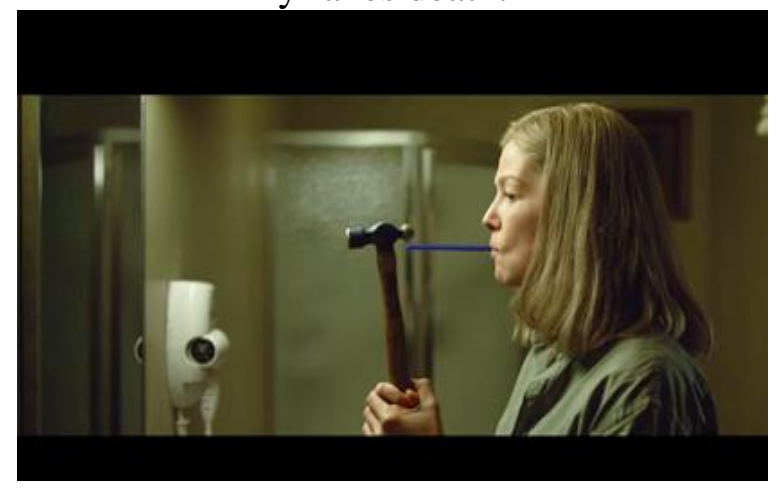

Image 3

Amy is about to hit her eye with hammer Also, Amy manipulates Noelle, sharing fake story to her about Nick abuses her, spending credit card on Nick's name to buy expensive stuffs to drain Nick's money, has Nick bumped her life insurance, fakes her pregnancy from Noelle's urine, writes diary consisting Nick abusive life story with different colors pen so it looks like Amy has been writing it for long time ago and purchases cheap car to escape in small resort, also she manipulates another crime scene when Amy wants to go back to Nick, so she has to kill Desi to leave no witness, so when Desi is not home, she begins with pouring coffee to her underwear and running in front Desi's security camera then screaming like she is abused by Desi, after Desi comes home she seduces him to have sex with her then slashes his Neck with box cutter and covered herself with Desi's blood that will be used to blame Desi that he has kidnapped and abused her, Amy manipulates everyone to believe in her story and she succeeds to have her revenge on Nick. 


\section{Lack of Remorse and Guilt}

Psychopaths have a lack of concern or feelings for the losses, pain, agony, and suffering of their victims; they may be still calm without any regret even after doing their action (Verstappen, 2011: 7). In Gone Girl film, Amy's character is developed as sadistic person, in fact that she tells Nick that she slashed and killed Desi without any regret towards him even though Desi has helped her and gave her a luxurious place to live, she is still calm while telling Nick.

\section{Amy: "I've killed for you, who else can say that? You think you would be happy with a nice Midwestern girl? No way baby,I'm it."}

(Scene 270 at minute 02:21:47 - 02:22:00)

\section{Shallow Affect}

Psychopaths can turn emotions "on" and "off" quickly, they also get angry if they do not get what they want. In this case, Amy shows her changing expression how she manipulates Desi to get his empathy, from normal expression to crying and suddenly back to normal expression again as seen from the image below:

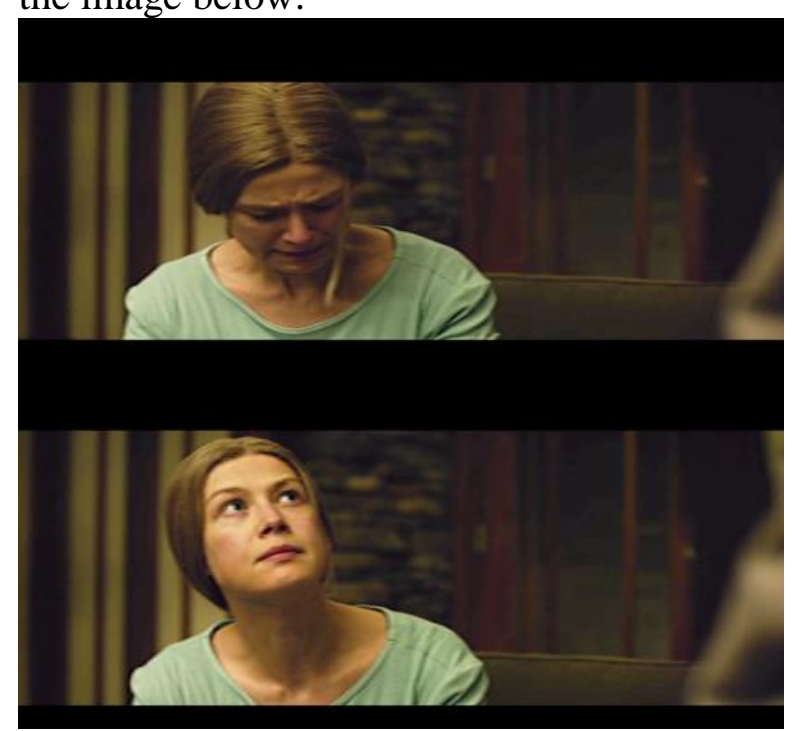

Image 4

Amy Changes Expression Rapidly

\section{Callous and Lack of Empathy}

Hare (2016) stated psychopath is unable to get into the skin of others and lack of empathy toward people's feeling. Furthermore, Amy does not even realize and appreciates how kind Desi was after all his kindness she has given to her like giving her place to settle down, buying her decent clothes to wear, buying her foods to eat, instead she kills him in very bad way.

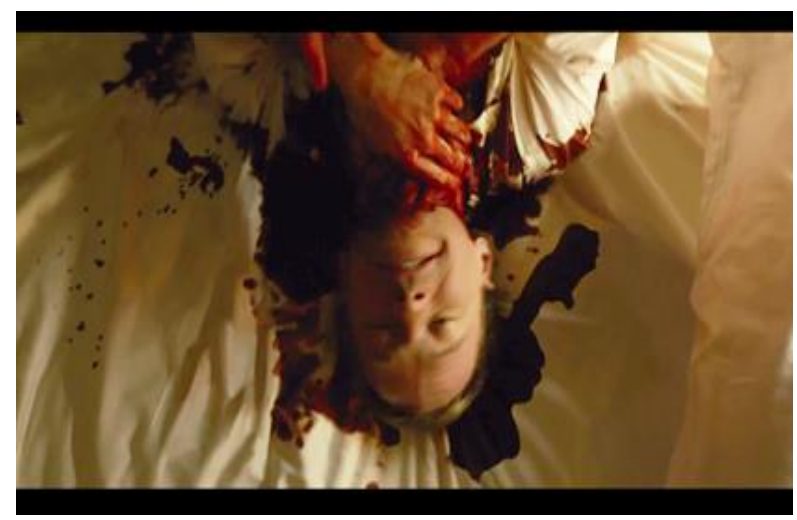

Image 5

Amy Kills Desi.

She confesses to Nick like it is not a big deal to kill someone, and the way she is very calm while saying that makes her a completely sadistic person who does not have empathy.

\section{Parasitic Lifestyle}

Psychopath will use their charm to seduce their victim's mind to help achieving their goals. Moreover, Amy has a specific characteristic showing her parasitic lifestyle behavior by the fact that Amy needs her neighbor, Noelle to be her testimony to the police and media of her fake story about Nick abuses Amy. Thus, Amy also needs help from Desi when she has no money anymore to support her life after getting robbed by Greta and Jeff. Those reasons show Amy leans on people's hand to complete her revenge on Nick and have a parasitic lifestyle. 


\section{Poor Behavior Control}

Psychopaths tend to have reactive character, and poor behavior control. In this case, Amy has very poor behavioral control over her by the fact that when their second marriage anniversary, Amy intended to give Nick prize by making envelops which Nick has to solve to know where the prize is located, she wrote down the envelops about the prize is located in library then she seduced Nick to have sex in quite corner in the library which is basically a public area. This shows that Amy has a poor behavioral control over herself

\section{Promiscuous Sexual Behavior}

Psychopaths have a lot of sexual relationships, bunch of affairs, and have sex relationship with any sexual partners, with intention of getting advantages from their prey (Meyers, 2014). In addition, when Amy's intention on getting revenge on Nick almost ruined because she has no money left after getting robbed, she seeks help from Desi who was her ex-boyfriend that she did not like anymore, she takes advantages from him to be her stop-over place: she lives in his luxurious lake house, wears decent clothes he bought, until she kills him with a box cutter to back home to Nick. It is revealed Amy has serious promiscuous sexual behavior on her.

\section{Criminal Versatility}

Psychopath is able to commit from one crime to another crime for many different advantages purposes and taking great pride of getting away from caught from crimes. Criminally speaking, Amy has committed so many crimes. For instance when Amy is faking her own death, lying to police, identity falsification, buying stuffs on Nick's credit card name, Killing Desi, Blaming Desi for kidnapping and abusing her. Those are obvious proofs that Amy is a serious criminal.

\section{CONCLUSION}

\section{Conclusion}

Conclusively, Gone Girl is one of the most thrilled-psychological story telling how Amy and Nick as a couple are lying to each other, hating on each other, and finally solving the problem then having their reunion in a horrible way. In addition, the writer analyzed the number of psychopathic symptoms Amy has. Eventually, the writer revealed the issues of their relationship happened when Nick started to lose his interest in Marriage, been lazy all the time, on the top of that conflicts when Amy found out that Nick was cheating with Andie, a student of him. Moreover, the writer also revealed that Amy has 9 out of 20 psychopathic symptoms which are Glib and Superficial Charm, Pathological Lying, Conning and Manipulative, Lack of Remorse and Guilt, Callous and Lack of Empathy, Shallow Affect, Parasitic Lifestyle, Poor Behavior Control, Promiscuous Sexual Behavior, Criminal Versatility. Eventually, Amy turned out to be murderous calculating psychopath in order to have revenge on Nick because he cheated on Amy and to be someone she did not agree to marry, thus, wanted Nick to be a husband she desired over again.

\section{Suggestion}

In order to conduct a research, regarding for another researchers who will choose movie review as their topic, it should be considered to concentrate on problems that related to each other, apply concrete and valid theory from well-known authors. Especially if choosing psychoanalytical review on Gone Girl film as a subject that will be conducted, the writer sees there are more point of views in analyzing Gone Girl film, therefore the writer suggests the next researcher should analyze about Amy's personality disorder like Borderline Personality Disorder, Narcissistic Personality Disorder, Histrionic 
Personality Disorder, or else about symbolism in Gone Girl film.

\section{REFERENCES}

American Psychiatric Association. 2013. Diagnostic and Statistical Manual of Mental Disorders, Fifth Edition. Virginia: American Psychiatric Association. ISBN: 978-0-89042-5541 (Hardcover), ISBN: 978-0-89042555-8 (Paperback)

Babiak, P., Craig Neumann, and Robert Hare. 2010. Corporate Psychopathy: Talking the Walk. Behavioral Science and the Law. p.174-193. DOI: 10.1002/bsl. URL: www.interscience.wiley.com

Bonn, Scott. 2015, June 15. Diagnosing and Managing Criminal Psychopaths: Criminal psychopaths can be managed but not cured. Accessed on April 12, 2017.

URL: https://www.psychologytoday.com/blo $\mathrm{g} /$ wicked-deeds/201506/diagnosingand-managing-criminal-psychopaths

Buzina, N. 2014. Psychopathy- Historical Controversies And New Diagnostic Approach. Psychiatria Danubina, Vol. 24, No.2, p.134-142. Retrieved from www.antoniocasella.eu/archipsy/Buzin a_2012.pdf

Cope, L. M, et al. 2014. Psychopathic traits modulate brain responses to drug cues in incarcerated offenders. Frontiers in Human Neuroscience, Vol.8, No.87, p.1-16. doi:10.3389/fnhum.2014.00087

Dasmart, F., T. Razinjoo, and V. Salehi. 2012. The Relationship between Psychology and Literature. Journal of Basic and Applied Scientific Research, Vol.2, No.9, p.9420-9423. ISSN: 20904304

Hancock, B., E. Ockleford, \& B. Windridge. 2009. An Introduction to Qualitative Research. Leicester: National Institute For Health Research (NIHR)
Hare, Robert. 2016, June 9. This Charming Psychopath: How to spot social predators before they attack. Accessed on April 12, 2017. URL: https://www.psychologytoday.com/arti cles/199401/charming-psychopath

Hare, Robert. 1999. Without conscience: the disturbing world of the psychopaths among us. New York: Guilford Press. URL: www.rdseastmidlands.nihr.ac.uk

Hasson, U, et al. 2008. Neurocinematics: The Neuroscience of Film. Projections, Vol.2, No.1, p.1-26. doi:10.3167/proj.2008.020102. ISSN 1934-9688 (Print), ISSN 1934-9696 (Online)

Hirstein, William. 2013, January 30. What Is a Psychopath? The neuroscience of psychopathy reports some intriguing findings. Accessed on April 12, 2017. URL:

https://www.psychologytoday.com/blo $\mathrm{g} /$ mindmelding/201301/what-ispsychopath-0

Keysers, Christian. 2013, July 24. Inside the Mind of a Psychopath - Empathic, But Not Always. Accessed on April 12, 2017.

URL: https://www.psychologytoday.com/blo g/the-empathic-brain/201307/insidethe-mind-psychopath-empathic-notalways

Kiehl, K. A., \& Buckholtz, J. W. 2010, September 1. Inside The Mind Of A Psychopath. Scientific American Mind. URL:

https://www.scientificamerican.com/ar ticle/inside-the-mind-of-a-psychopath/

Leistedt, S., and Paul Linkowski. 2013. Psychopathy and the Cinema: Fact or Fiction. Journal of Forensic Science, p.1-8. doi: 10.1111/1556-4029.12359. URL: onlinelibrary.wiley.com

Meyers, Seth. 2014, October 7. Sex and the Psychopath: Why so many fall for psychopaths, and how they can begin to heal. Accessed on April 12, 2017. URL: 
Totobuang, Vol.5, No. 2, Desember 2017: 187-198

https://www.psychologytoday.com/blo g/insight-is-2020/201410/sex-and-thepsychopath

Montana Legislative Services. 2015. Montana Code Annotated. Accessed on April 15, 2017. URL: http://leg.mt.gov/bills/mca/46/14/4614-304.htm

Niemiec, Ryan. 2014, October 14. The Strengths of the Gone Girl Psychopath. Accessed on July 13, 2017. URL: https://www.psychologytoday.com/blo $\mathrm{g} /$ what-matters-most/201410/thestrengths-the-gone-girl-psychopath

Sharma, R., Ajeet Sidana, and Gurvinder Pal Singh. 2007. Pseudologia Fantastica. Delhi Psychiatry Journal, Vol.10,
No.1, p.78-80. URL: medind.nic.in/daa/t07/i1/daat07i1p78. pdf

Sheen, Erica. MA in Film and Literature. Accessed on April 12, 2017, from https://www.york.ac.uk/english/postgr aduate/taught-ma/film/

Verstappen, Stefan. 2011. Defense Against The Psychopath: A brief introduction to human predator. Toronto: Woodbridge Press. ISBN 978-0-9869515-2-7

World Health Organization. 2016, April. Schizophrenia. Accessed on December 02, 2016, from http://www.who.int/mediacentre/factsh eets/fs397/en/ 